\title{
TEMPO, HISTÓRIA E A ESCRITA DA HISTÓRIA: A ORDEM DO TEMPO*
}

\author{
François Hartog
}

EHESS

\section{Resumo}

O artigo procura circunscrever historicamente uma série de reflexões que a experiência da temporalidade situa para o historiador contemporâneo a partir da proposição da noção de regime de historicidade, especialmente contrapondo sua formulação moderna, estruturada pela idéia de Progresso, à antiga, polarizada pelo topos da historia magistra vitae.

\section{Abstract}

This article tries to circunscribe in terms of History a set of reflections about the experience of temporality. For the modern historian this experience derives from the "régime d'historicité" which is structured by the idea of progress in oposition to the ancient "topos" of "historia magistra vitae".

\section{Pallavras-Chave}

Regime de Historicidade • Temporalidade • Escrita da História • História $\bullet$ Historia Magistra Vitae

\section{Keywords}

"Régime d'Historicité" • Temporality • The Writing of History • History • "Historia Magistra Vitae"

*Tradução do Prof. Dr. Francisco Murari Pires - Departamento de História - FFLCH/USP. 
$\mathbf{H}_{\mathrm{a}}$ á uma Sociedade Internacional para o estudo do tempo que aparentemente se reúne desde 1969. Não é esta a via científica que vou seguir. Antes, lembrarei primeiro uma citação de Agostinho: "Nos tempora sumus" (nós mesmos somos tempo) e começarei por uma questão bem simples. Seria significativo considerarmos nossa atual situação, digamos a partir de 1989, do ponto de vista de nossas relações com o tempo? Lança alguma luz reintroduzir a questão do tempo ou tratar o tempo como questão? Não detenho direito especial para fazê-lo: vindo de um passado remoto, não posso me apresentar como praticante do que, bem sugestivamente, os alemães chamam de Zeitgeschichte, a significar história do presente.

A fim de formular uma possível resposta, proporei uma viagem de duas vias, do século XX para a Mesopotâmia antiga e de volta. Certamente demasiado longa e demasiado curta! Bem, faremos apenas algumas paradas, escolhidas por oferecerem ao viajante tanto algo similar ao que agora experienciamos quanto, ao mesmo tempo, nítidas diferenças. Não irei considerar todas as formas de tempo ou experiência temporal, mas apenas aquelas que pertencem à tradição do saber: mais precisamente, os modos por que se conectam presente, futuro e passado na escrita da história. Estas configurações intelectuais compõem apenas uma camada nas relações complexas e intrincadas para com o tempo mantidas por toda sociedade a cada momento, uma trama percorrendo a tapeçaria.

O historiador vive quotidianamente o tempo, mas mesmo que ele não mais se interesse, no dizer de Benjamin, pelo tempo linear "homogêneo" e "vazio", ele corre o risco de simplesmente instrumentalizar o tempo. Constitui também tarefa do historiador tentar pensar sobre o tempo, não sozinho, é óbvio. Diante de nós, houve vários momentos em que o tempo foi objeto de uma intensa reflexão, especulações, medos, sonhos, por exemplo ao fim do século XVI ou por volta de 1900.

Por que 1989? Bem óbviamente, por causa da queda do Muro de Berlim. 1989 não significa de modo algum o fim da história (ou seja, segundo F. Fukuyama [1995: 27-44], a democracia, entendida como a forma final dos governos humanos e a História concebida como um processo evolutivo simples e coerente). Talvez, o ponto mais interessante não fosse tanto o livro em sua receptividade imediata - com todos os 
seus equívocos - e seu grande sucesso pelo mundo afora. 1989 significaria antes o fim (ou pelo menos uma nítida quebra) do que denomino o regime moderno de historicidade (regime d'historicité), que começou por volta de fins do século XVIII (Die Neuzeit, segundo as análises de R. Koselleck 1985). Grosso modo 1789-1989, podem ser selecionadas como duas datas simbólicas. Tal é a principal hipótese que gostaria de considerar aqui.

No que respeita à historiografia, a expressão moderno regime significa um período em que o ponto de vista do futuro domina. A palavra-chave é Progresso, História é entendida como processo e Tempo como se direcionando a um fim (progressão). O fim deste regime moderno significaria que não é mais possível escrever história do ponto de vista do futuro e que o passado mesmo, não apenas o futuro, se torna imprevisível ou mesmo opaco. Deve ser reaberto. Mas como o veremos? Que questões devemos colocar?

O que temos experienciado por uns vinte anos nas ciências sociais é, no mínimo, uma certa perplexidade (fim dos grandes modelos, pós- isto ou aquilo). Mas desde 1989, especialmente entre os historiadores, uma frase apareceu com uma singular frequiência: a necessidade ou a falta de "orientações". Por em questão o tempo nos ajudaria a encontrar uma orientação? Ofereceria uma guia? Como devemos proceder? Por uma precisa análise de nosso presente e de nossas relações presentes com o tempo, no Ocidente mas também no antigo Leste. Também esboçando um enquadramento comparativo: tomando em consideração momentos do passado em que um regime de historicidade foi questionado ou chegou ao fim: momentos em que as relações da sociedade com o tempo entraram em crise. Momentos de crise do (no) tempo. Mesmo que elas esbocem uma longa jornada pelo tempo, as observações que seguem, que partem da nossa situação atual e intentam retornar a ela, constituem apenas uma primeira abordagem.

\section{Regime de historicidade}

Esta noção que estou propondo aqui difere da de época. Época significa, no meu entender, apenas um corte no tempo linear (de que freqüentemente se ganha cons- 
ciência após o fato e bem depois ela pode ser usada como um recurso de periodização). Por regime, quero significar algo mais ativo. Entendidos como uma expressão da experiência temporal, regimes não marcam meramente o tempo de forma neutra, mas antes organizam o passado como uma seqüência de estruturas. Trata-se de um enquadramento acadêmico da experiência (Erfahrung) do tempo, que, em contrapartida, conforma nossos modos de discorrer acerca de e de vivenciar nosso próprio tempo. Abre a possibilidade de e também circunscreve um espaço para obrar e pensar. Dota de um ritmo a marca do tempo, e representa, como se o fosse, uma "ordem" do tempo, à qual pode-se subscrever ou, ao contrário, e o que ocorre na maioria das vezes, tentar evadir-se, buscando elaborar alguma alternativa.

Quanto ao regime moderno, cito Tocqueville: "Quando o passado não mais lança luz sobre o futuro, o espírito caminha nas trevas". Ele alude aqui (ao término de $D e$ la Démocratie en Amérique) à grande Revolução em curso. Esta sentença convenientemente esboça o que se poderia chamar o antigo regime de historicidade. Antes, ou seja, quando a relação entre o passado e o futuro era dominada ou regulada por referência ao passado, com o futuro não reproduzindo o passado, mas não indo além, o espírito sabia para onde estava indo.

Do ponto de vista da escrita da história, era o tempo em que o topos da história como mestra da vida era plenamente válido. Tocqueville parece-me particularmente interessante, uma vez que ele constitui uma boa testemunha para este momento de corte e reversão nas relações entre passado e futuro.

Como escrever história a partir de então? A fim de compreender melhor o passado, ele viajou para o, ou no, futuro, isto é, ele visitou em 1831 os Estados Unidos para estudar a nova sociedade, a democrática. Mas ao mesmo tempo, Tocqueville contradisse mais fortemente do que qualquer outro a apresentação que a Revolução deu de si mesma como uma quebra radical. Pelo contrário, ele insistiu na continuidade entre a monarquia (enquanto absolutismo) e a Revolução, notadamente no que respeita à centralização. Assim lançandose no futuro, ao escrever a partir do ponto de vista do futuro, ele obteve uma confirmação de sua tese principal. Sua comutação para o novo (ou moderno) regime de historicidade permitiu-lhe ir além do enfoque de que a Revolução fosse um começo absoluto. 
No regime moderno, no lugar de diversas histórias, história vem a ser compreendida como um processo único: "além das histórias há História”, escreveu Droysen. Até meados do século XVIII, a expressão “die Geschichte(n)" era geralmente empregada no plural, mas depois a forma plural "condensou em um coletivo singular". A partir de então, os acontecimentos não ocorrem apenas no tempo, mas antes pelo tempo e história torna-se menos um relato de exempla do que uma narrativa do unívoco (Koselleck 1985: 31, 246). Consequentemente, não há mais lições diretas da história, mas ganha-se cada vez mais ansiedade quanto a previsão. Na historia magistra, a exemplaridade vinculava o passado ao futuro enquanto um modelo a ser rivalizado pelo leitor. Na moderna concepção de história, a exemplaridade cede lugar ao unívoco. Algum dia, no futuro, alguém estabelecerá uma lei. Ou, para empregar uma outra formulação típica de fins do século XIX, algum dia no futuro virá o dia glorioso da "synthèse", mas por enquanto “c'est l'ordinaire ingrat de l' analyse"! O passado necessariamente é obsoleto. O escritor Julien Gracq registrou certa vez que "História tornou-se, essencialmente, uma admoestação dirigida ao presente pelo Futuro". Acrescentaria apenas que a admoestação estendeu-se também ao passado e se impôs aos historiadores. No decorrer do século XIX, eles organizaram sua disciplina como uma ciência do passado, mas esta ciência por sua vez tornou-se teleológica: mostrou como o moderno Estado-nação se desenvolveu de origens remotas no passado. Se há alguma lição, ela vem, por assim dizer, do futuro, e não mais do passado.

Antes de retornar à crise do regime moderno, e a fim de esboçar um quadro geral, tratarei brevemente de duas questões: o destino da Historia magistra e o que poderia ser chamado de a pré-história da historicidade.

Historia magistra, se a formulação é latina e vem de Cícero (abordando o orador), sua concepção é já grega. Forma-se no século IV a.C., ou mesmo no V, com Tucídides e a definição de sua obra como um ktêma para sempre. Mais tarde, a história se apresenta como uma coletânea de exemplos. Em princípio a história era designada para aquele que se supunha fazer a história: a assembléia popular, o orador, os governantes romanos, posteriormente o príncipe. Por quanto tempo perdurou a historia magistra? A resposta não é tão simples. Se seguirmos R. Koselleck, 
sua dissolução ocorreu apenas na segunda metade do século XVIII: na Alemanha com a formação do moderno conceito de história e na França com a Revolução. Significa isto que a historia magistra manteve-se no cargo sozinha por mais de vinte séculos?

Antes de tudo, não reconhecer que houve um regime cristão, com sua história orientada pela salvação, seria difícil (Kemp 1991). Todavia, concentrar-me-ei apenas em quatro observações:

1) a historia magistra antecedente (pagã) sobrepôs-se ao conceito cristão de história, pelo menos até Eusébio e Agostinho.

2) Ao longo da Idade Média, a dimensão da historia magistra ficou talvez subordinada, cristianizada, mas não desapareceu de todo. "Quaecumque scripta sunt ad nostram doctrinam scripta sunt" (Paulo). Nenhum historiador medieval duvidou de que a história provia "exemplum vitae". Levou tempo para que se formulasse este novo regime teológica e historiograficamente: mais ou menos quatro séculos. Eusébio, bispo de Cesarea, ao compor sua História Eclesiástica (a história desta nova nação, a cristã), tomou como seu ponto de partida "a primeira ordenação (oikonomia) de Deus concernente nosso Salvador e Senhor Jesus Cristo". Agostinho escreveu sua Cidade de Deus (com suas duas cidades) após o saque de Roma (410) e, de certo modo, como resposta a ele. Mais tarde, Isidoro de Sevilha ou o venerável Beda sustentaram esta dimensão exemplar. Estes homens, mais outros, são responsáveis pela escrita da história eclesiástica "nacional” ("Historiam Gentis Anglorum Ecclesiasticam...).

3) Obviamente, o topos da historia magistra em geral ganhou nova e maior importância no Renascimento, com a redescoberta e leitura dos historiadores antigos, pondo-se ênfase na imitação dos antigos e, em termos mais amplos, no uso da Antigüidade como um instrumento polêmico de crítica à Cristandade.

4) Para dar um último exemplo da reformulação da historia magistra, que nos leva de volta ao século XVIII, o francês Abbé Rollin publicou seu bem influente livro Traité des Études (1726), tendo um capítulo acerca da "Utilidade do aprendizado da história", e mesmo história pagã, porque a história é "a escola comum de toda a raça humana". Não apenas o príncipe, mas também os súditos. 


\section{A pré-história da historicidade}

Duas experiências parecem-me fascinantes do ponto de vista das relações com o tempo, ou, mais precisamente, do ponto de vista do modo pelo qual elas articulam presente, futuro e passado: a Mesopotâmia antiga, por inícios do II milênio a.C., e a Grécia antiga, em torno do século VII.

Primeiro, a Mesopotâmia antiga:

Em um contexto de forte afinidade, pode-se constatar: a) o lugar ocupado pela adivinhação no processo de tomada de decisão; b) a grande importância da escrita, nas mãos de uma casta (de escribas). Para organizar seu conhecimento, compuseram listas, listas de tudo, dentre outras coisas, oráculos, e usaram, notadamente, oposições binárias como um princípio de classificação; c) No acadiano, o tempo passado é designado por um termo que significa “na frente”, e o futuro é dito “o que está atrás” (Glassner 1993).

Durante o sacrifício tem-se que o Deus firma, isto é, escreve, o signo que o adivinho lê. Como? "Indo" (efetivamente ou apenas por meio de sua memória) à sua biblioteca, à busca de um precedente (Bottéro 1974: 70-193). Se houver um, sem problemas. Mas, obviamente, nunca se pode estar absolutamente certo, dado que a adivinhação é uma ciência sistemática do passado, mas do caso singular, que procede por meio de acumulação de casos para os quais a generalização está, por definição, fora de alcance. Se não há, tem-se que arriscar uma interpretação, em compilando e combinando oráculos anteriores. A adivinhação pode ser primeiro vista como uma ciência do passado, mas um passado que aparece na forma encapsulada (forma jurídica?) do precedente e que não guarda valor em si.

Dentre os milhares de oráculos preservados, há uma categoria chamada pelos modernos de "oráculos históricos". Encontrados em Mari, estão entre os mais antigos (inícios do II milênio a.C.), escritos diretamente sobre modelos de argila que reproduzem o fígado do animal. Muito estranhamente, não estão redigidos consoante o padrão normal: "Se o fígado da ovelha tiver esta aparência (há aqui uma descrição altamente técnica), isto é o signo de que o rei irá tomar a cidade de um certo modo". Antes dizem: "Presságio do rei que tomou a cidade", empregando não o futuro, mas o passado. Por exemplo: “Se o 'portal do palácio' (uma parte do fígado) é duplo, o 
rim triplo, e há dois cortes do lado direito da vesícula, é presságio do governante Apishaliano, a quem Naram-Sin fez prisioneiro após romper a muralha de sua cidade”.

O que isto significa exatamente? Não sei, mas está pelo menos claro que é um signo de como os adivinhos trabalhavam, fazendo suas tarefas em seus recintos e bibliotecas. Os acontecimentos a que aludiam são geralmente considerados pelos especialistas modernos como históricos (reais). Daí a idéia, defendida por alguns deles, de que os textos de presságios estão nas raízes mesmas de toda a historiografia mesopotâmica, gozando de precedência, tanto no tempo quanto na confiabilidade, sobre qualquer outro gênero que tratasse do passado. Não há porque ir tão longe? Todavia, no extremo, um escriba que quisesse redigir uma crônica histórica, poderia fazê-lo compilando uma série de oráculos "históricos" (sem as prótases, "Se...") e os adivinhos podiam (e de fato o fizeram) copiar inscrições históricas, celebrando vitórias de reis anteriores, a fim de armazená-las, completar suas coleções de apódoses, e elaborar novos oráculos: os "oráculos faltantes" em suas listas.

Antes do que oráculos históricos, preferiria chamá-los de oráculos exemplares. Por que? Porque a maioria trata de um período específico (fins do III milênio, inícios do segundo) e dos grandes governantes da época. Seu foco cai sobre o destino da dinastia acadiana, com as duas figuras opostas de Sargão e Naram-Sin, que posteriormente adquiriram valor paradigmático como bom e mau rei. Assim, para dizêlo de modo bem esquemático, com tais oráculos poderíamos nos situar entre o precedente e o exemplar, entre adivinhação magistra e historia magistra.

Os gregos aqui surgem como tardios. Eles optaram por outra via, por outro passado e um seu outro uso. Se as diferenças para com os mesopotâmios são notáveis, a adivinhação está também presente. O primeiro texto que deparamos é a épica com os poemas homéricos (séculos VIII e VII). O mundo épico baseia-se na economia da glória imortal (kleos): concorda-se em morrer na guerra em troca de obter-se glória imortal, por meio dos cantos do poeta inspirado (é disso que trata a história de Aquiles). A épica funciona como uma memória social para um grupo de aristocratas.

Mas com a Odisséia o modelo épico já foi questionado. A Odisséia ocupa o lugar de uma "história" face à Ilíada. Ela vem depois, ela trata não apenas ou pri- 
mordialmente da morte heróica, mas antes da memória e da ausência. Cena famosa: solicitado por Ulisses, o cantor dos feáceos canta o episódio do Cavalo de Madeira e os feitos do herói. Ulisses põe-se a chorar. Nesses versos, em que Hannah Arendt reconhece bem a primeira narrativa histórica, Ulisses tem uma experiência exterior, a de alguém que observa a história de sua própria vida, deslocando-se da primeira para a terceira pessoa e assim perdendo sua própria identidade (como se estivesse morto). Por meio desta experiência penosa de situar-se à distância de si mesmo ou, por assim dizer, de não se situar no tempo consigo mesmo, pode-se, acredito, descobrir historicidade, como o fez Odisseu. Seu retorno delongado o expressa amplamente (Hartog 1996).

O fato é que, dois séculos depois, o primeiro objetivo de Heródoto será o de impedir o oblívio ou pelo menos retardá-lo. O tempo é visto como o inimigo e o passado é menos concebido como uma coletânea de precedentes do que como uma história que tem que ser contada e lembrada.

Neste rápido apanhado de, por assim dizer, uma pré-história de um regime de historicidade, meu propósito não foi misturar história com adivinhação, menos ainda reduzí-la a adivinhação, ou mesmo pretender que houvesse uma única linha que leva da primeira à segunda. Mas, na medida em que se busca uma orientação para a ação, elas apresentam uma certa proximidade intelectual. Deixei de lado o uso da adivinhação entre os gregos para enfocar apenas o modo pelo qual eles optaram, por meio da épica, por um passado diferente. A questão seguinte, seria: partindo dessas premissas como poderíamos entender a emergência da historia magistra, dado que, quando Cícero a formulou, o jogo estava já em curso há longo tempo? Deixoo de lado, e salto Eusébio e Agostinho para alcançar o século XVI.

\section{Os momentos de questionamento de um regime de historicidade}

O primeiro momento que vou tomar em consideração é o período em torno de 1570-1580 na França. Este foi um período de grande agitação religiosa e política (Guerras Religiosas de 1562-1598, Massacre de São Bartolomeu de 1572). Mais ainda, havia o problema geral de como encarar intelectualmente o Novo Mundo. O 
que podemos de imediato constatar entre os intelectuais é uma intensa preocupação com, ou mesmo ansiedade acerca da história e do tempo. Aqui vão três casos breves.

Em 1566, J. Bodin publicou o seu O Método da História. Assim que se lê o Prefácio, deparamo-nos com Cícero e sua historia magistra: "É graças à história que o presente é facilmente explicável, que penetramos no futuro e que obtemos indicações bem seguras sobre o que convém procurar e evitar". E nos é ainda dito que "Afonso e Fernando, reis de Espanha e da Sicília, recuperaram a saúde ao reler um Tito-Lívio, e o outro Quinto Cúrcio, quando os médicos haviam admitido sua impotência”! Até aqui, temos um mundo familiar: a luz brilha do passado sobre o presente e o futuro. Mas, se passamos à página seguinte, lemos que a história toma três formas: humana, natural e divina; uma divisão que realmente não apresenta sabores ciceronianos. Bodin então passa a atacar a teoria histórica de longa data dos quatro impérios e a visão dos inícios como um tempo de pobreza e pureza. Pelo contrário, os inícios não foram uma Idade do Ouro, mas uma época de superstições e de crueldade. O questionamento da autoridade do passado parece clara. Mas, como mostrou convincentemente A. Grafton, o ataque mesmo repousa no uso de uma autoridade antiga: a História de Tucídides, onde, na assim dita Arqueologia, Bodin "encontrou o arcabouço intelectual para seu próprio argumento" (1994: 1401-1405). E ao fim do livro, está-se menos do que seguro de que Bodin está simplesmente reavaliando o mote da historia magistra.

Em 1575, Loys le Roy, humanista bem conhecido, publicou De la vicissitude ou variété des choses en l'univers. O livro constitui um interessante fracasso, porque se Le Roy conhece o que pensa, não sabe como o pensa! Falta-lhe um conceito apropriado de tempo e uma noção apropriada de comparação. O livro baseia-se na historia magistra e ao mesmo tempo a desafia, ao tentar provar a superioridade do presente. Ele faz uso simultaneamente de várias temporalidades: tempo de orientação cristã e tempo cíclico, como começo, florescimento e declínio, conveniente para a explicação das "vicissitudes". Mas como combiná-lo com o presente visto como superior a qualquer tempo anterior? Significaria que o declínio está armazenado para nós? 
Os capítulos finais intentam refutar a idéia de que nada de novo pode ser dito em se fazendo uso de autores antigos para provar que o progresso é possível: "Platão diz que os gregos aperfeiçoaram o que receberam dos bárbaros. A opinião de Cícero era de que os italianos fizeram melhores invenções do que os gregos, ou melhoraram o que tomaram de empréstimo a eles. E por que não nos empenharíamos em fazer o mesmo; corrigindo o que os bárbaros, os gregos e os romanos nos deixaram". Muito poderia ser dito acerca desta formulação, como se Le Roy estivesse a usar a historia magistra justamente para ir além dela e fortalecer o status do presente.

Em 1580 foram publicados os dois primeiros livros dos Ensaios de Montaigne. Montaigne experienciara a impossibilidade de ser um novo Plutarco.

a) Ele fez um uso extensivo de exemplos. Os exemplos foram selecionados justamente porque eles são potencialmente um apelo à imitação e generalização. Como o formulou J. Starobinski: “o passado do exemplo é habitado pelo futuro do deverser” (1982: 30). Mas quando se toma ciência da variedade e contradição dos exemplos, não se pode deixar de pensar que eles tendem a se autodestruir. O exemplo se volta contra si mesmo, sem se ter deixado o enquadramento da história exemplar. O exemplo em Montaigne perde sua capacidade de ser generalizado (ou de se apresentar sob uma forma de generalização) e tende a se tornar uma curiosidade, que atesta apenas a fantástica variedade do mundo. Considerados a partir desta perspectiva, o primeiro e os últimos capítulos do livro são particularmente esclarecedores: "Por diversos meios chega-se a igual fim" e "Acerca da Experiência". Por fim, "a vida de César não comporta mais exemplos do que nossa própria vida".

b) O tempo tudo desestabiliza e torna impossível escrever sua própria vida como uma plutarquiana. "Eu não pinto o ser. Eu pinto o movimento". Consequentemente, Montaigne, por assim dizer, retira-se para dentro do presente.

Todos estes exemplos têm em comum, no meu entender, uma grande preocupação acerca do tempo. E pode-se mesmo reconhecer os delineamentos de uma perspectiva historicista. Eles tentam simultaneamente confiar na historia magistra (notadamente de modo polêmico) e, ao mesmo tempo, questioná-la profundamente, 
ou ainda pior usá-la e solapá-la. Por que, a despeito deste questionamento, a historia magistra permaneceu afinal de contas em uso? Talvez dois direcionamentos apontem uma resposta: o lugar das Igrejas e das instituições religiosas (precisamente por seu reciclar da historia magistra) e a formação das grandes monarquias (notadamente em sua versão absolutista).

Podemos apontar um segundo momento de questionamento que se situa, por assim dizer, entre dois regimes de historicidade: entre a dissolução da historia magistra e a implementação do regime moderno. Como vimos antes, Tocqueville é uma boa testemunha, mas ele já esta atuando como historiador intentando dar um sentido ao passado (recente). Como se passam as coisas com os atores mesmos, os Revolucionários, confrontados que estavam com a urgente questão de qual decisão tomar e como agir? Certamente, fizeram um uso intenso do passado, especialmente do antigo ou passado plutarqueano, de modo a que assim parecem seguir os padrões tradicionais da historia magistra, mas ao mesmo tempo proclamam sua recusa em se envolverem com a imitação. Eles afirmaram a absoluta novidade do seu empreendimento (o novo calendário, por exemplo, como expressão de um novo tempo). Como se tivessem um pé numa margem e o segundo na outra (Saint Just, por exemplo, no Rapport du 26 Germinal an II: "Nada desprezai, mas nada imitai do que ocorreu antes de vós; o heroísmo não tem modelos", Hartog 1993: 301).

A figura de Napoleão pode também nos dizer algo. Poder-se-ia escrever uma biografia (se não foi já feita), apresentando-o como o pobre homem pego entre dois regimes de historicidade! Tanto o regime moderno, expresso pela Revolução, e o antigo modelaram seu pensamento e sua conduta. Mas tudo se passa como se seu comportamento se tornasse cada vez mais dominado pelo padrão antigo e apelo à imitação, como se ele pudesse apenas ir para trás rumo ao futuro. Como leitor de Plutarco tinha fascínio por Alexandre Magno. Como Alexandre, que, após ter derrotado Dario, o rei persa, desposou sua filha, Napoleão desposou a filha do imperador austríaco, após ter destruído o Sacro Império Romano Germânico (e proclama seu filho como Rei de Roma). Caso perdido. Podemos nos valer também de um famoso quadro para dizer a mesma coisa. A "Batalha de Alexandre" foi pintada em 1529 
por Altdorfer (mostra a batalha de Issos entre os gregos e os persas). Napoleão, sem surpresa, apreciava-o deveras, tanto que em 1800 trouxe-o para Paris e colocou-o no castelo de Saint-Cloud, em ponto bem particular, seu banheiro.

Chateaubriand será minha última testemunha para este período. Toda sua obra pode ser lida como uma reflexão sobre o tempo - não apenas a mudança (le passage), mas também a experiência bem perturbadora de sua aceleração, experiência bem comum às pessoas daquele tempo (e um dos principais aspectos do regime moderno de historicidade), ou a ruptura que ocorre entre experiência e horizonte de expectativa. "Eu escrevia história antiga, e a história moderna estava a bater em minha porta; eu lhe gritava em vão: 'Espera, já vou' Ela passava ao estrondo do canhão, levando três gerações de reis". Foi escrito em 1831. Perseguido pelo tempo e a descoberta da história como processo, sua escrita é fundamentalmente histórica. Mas ao passo que a história em sua tentativa de se apresentar como uma disciplina científica, durante a segunda metade do século XIX, marcará uma nítida quebra entre o passado e o presente, Chateaubriand jamais deixa de cruzar a fronteira, ou mesmo de ultrapassá-la pelo projeto de suas Memórias de Além Túmulo ("As formas mutáveis de minha vida adentraram assim umas nas outras").

Mais precisamente, com ele podemos experienciar a dissolução da historia magistra: ele a empregou e descobriu sua falha. O primeiro problema por ele enfrentado foi: como compreender a Revolução e prever seu futuro? Podemos ler a resposta num grande e inacabado livro publicado em Londres em 1797, Ensaio Histórico sobre as Revoluções antiga e moderna, que se baseia no uso clássico dos paralelos. Ele não via nada de bom a se esperar e nada de realmente novo na Revolução Francesa. Mas ao rever seu livro vinte e cinco anos depois, publicou-o novamente com notas de rodapé, introdução prefácio etc., meios todos de que ele se valia para poder contradizer o que anteriormente escrevera (mas, obviamente, sem o suprimir). Como? Em considerando a descoberta americana do sistema representativo. Aqui, ele ofereceu uma versão americanizada da idéia de Benjamin Constant acerca das duas formas de liberdade, a antiga e a moderna (1819). Como sempre quando se trata de Chateaubriand pode-se constatar um revezamento perpétuo entre espaço e tempo: 
América e Antigüidade. De qualquer modo, entre os antigos e nós tem-se agora uma distância insuperável, razão por que o paralelo, enquanto recurso principal da historia magistra não tem mais validade para a escrita da história: visitar o passado ou antever o futuro desde o passado (Hartog 1994). No que respeita ao tempo, Napoleão caminha cada vez mais para trás, ao passo que Chateaubriand mergulha no rio, entre as duas margens: "Deparei-me entre dois séculos, como na confluência de dois rios; mergulhei em suas águas agitadas, afastando-me com pesar da velha margem em que nascera, nadando esperançoso rumo a uma margem desconhecida" (1951: 906).

\section{Questionamentos e crise do regime moderno}

Um regime certamente não é uma entidade metafísica, que desce dos céus, mas antes um arcabouço durável, que é desafiado tão logo se torna predominante ou simplesmente funcional. Como vimos, há períodos intermediários sobrepondo-se entre dois regimes principais. Nada automático nisto.

Obviamente, muito questionamento ocorreu em torno e depois da Primeira Guerra. Mas esta crise profunda (de que a questão do tempo constitui apenas uma expressão) não terminou com a formulação de um regime de historicidade novo ou diferente.

Um dos modos em que se expressaram as dúvidas tomou a forma de críticas então movidas contra o Historismus, ou, na França, contra a assim dita história positivista. O tempo era instrumentalizado como mera cronologia e a historiografia denunciada como narrativa superficial. Mais construtivas foram as várias tentativas de elaborar um novo conceito de história e definir novas temporalidades, o que fazia melhor justiça aos movimentos reais (i.e mais profundos) das sociedades passadas. Pode-se pensar em muitas obras em diversos campos. Selecionarei apenas algumas poucas. Nesta perspectiva, Walter Benjamin é a figura mais iluminadora. Entre 1920 e sua morte em 1940, ele tinha em mente elaborar um novo conceito de história, que romperia com a crença no progresso e com a idéia de que a humanidade avança em um tempo linear e homogêneo. Über den Begriff der Geschcichte é, como sabemos, o título de sua última obra. Não apenas que o tempo dê lugar à descontinuidade, como também Benjamin questiona a nítida quebra entre passado e presente. Ele 
desenvolve uma concepção do tempo que, partindo do presente, traz o passado à atualidade do presente, o guarda, tomando por sua base a noção de Jetztzeit e lidando com o que ele denomina "rememoração" (Eingedenken). "Er (der Historiker) begründet so einen Begriff der Gegenwart als der Jetztzeit, in welcher Splitter des Messianischen eingesprengt sind" (Benjamin 1974:704). A imagem que melhor expressa esta operação é o raio de um relâmpago: uma iluminação recíproca do passado e do presente, de um momento do presente e um do passado, apenas por um segundo ("É uma imagem única, insubstituível do passado que,, desvanece a cada presente que não soube se reconhecer em sua mirada", idem, 261). Isto significa que se olha no passado pelo futuro, de modo bem Bíblico, reconhecendo os aspectos que advirão. Mas para o historiador, o "historiador materialista", lidar com passado implica mais precisamente escrever em direção a um futuro que é agora passado: "Buscar o que, se bem que entretenimento passado e pervertido, conserva entretanto mais promessas que dele esconde a imagem atual do futuro", para dizê-lo nos termos de P. Szondi (s/d: 43). O historiador trabalha, para empregarmos a frase de F. Schlegel, como "um profeta do passado".

Benjamin poderia nos levar a Proust que ele traduziu para o alemão, e logo encontraríamos Bergson, então Ch. Péguy, o primeiro e mais agudo crítico da história positivista. Não é então por acaso que Benjamin tenha se tornado um pensador tão proeminente nos últimos vinte e cinco anos; há muitas razões, mas a sua interrogação acerca do tempo da história é certamente uma delas. Todavia, sua reflexão, dramaticamente interrompida, ficou entre o messianismo e a utopia: "Ursprung ist das Ziel" escreveu Karl Krauss, significativamente citado por Benjamin (1974: 701).

Entre os historiadores profissionais franceses, os críticos da história positivista, nos anos vinte, assumiram duas formas aparentadas. Elas foram dirigidas contra a história nacional concebida acima de tudo como história política do progresso da idéia da nação, e eles advogavam uma história econômica e social: uma história que cada vez mais se aprofundasse na sociedade. Mais profunda e mais verdadeira. Tomando a inspiração, principalmente, dos economistas e dos geógrafos, eles estavam de fato buscando diferentes formas de temporalidade, empregando noções tais 
como ciclos, conjunturas e todos os diferentes ritmos da história, logo levando rumo ao Méditerranée de Braudel e, nos anos cinquenta, à sua formulação da noção de "longue durée" e à proposição de um novo conceito de história definido como a dialética de diferentes tipos de duração: "uma dialética da duração" (Braudel 1969: 61). Depois, nos anos setenta, houve o encontro com o estruturalismo de Levi Strauss, mas ao preço de um desentendimento acerca da definição do que seja uma estrutura e de várias polêmicas sobre diacronia e sincronia.

Acrescentarei uma última figura, o poeta e pensador Paul Valéry, mas não vou discutir aqui as várias declarações que ele formulou contra a história nos anos trinta. A grosso modo, qualquer uso da história para enfrentar uma situação presente ou para conformar o futuro constitui um abuso, porque a história escrita pelos historiadores nada mais é do que gênero literário, que não se dispõe a reconhecer que ela o é. Não há diferença substantiva, afirmou, entre Balzac e Michelet. Poder-seia, de imediato, pensar em debates mais recentes. Mas atentarei apenas a uma nota de seus Cahiers, escritos em 1940, em que ele compara história e geologia: "A geologia é uma espécie de história - que se ela se limitasse a contar tais erupções prodigiosas, tal inundação célebre etc., ela faria o que faz a história com seus acontecimentos. Mas ela investiga as modificações lentas que ninguém um dia pode observar. O que a história deveria fazer" (Valéry 1974: 1503). Quem, quase no mesmo momento, empregará a metáfora geológica e introduzirá, por assim dizer, o tempo geológico na história ou sua concepção geológica? F. Braudel. Valéry se encontrava então na Inglaterra, e Braudel num campo de prisioneiros, onde ruminava seu Méditerranée. Para além de tudo que os separava, eles compartilhavam pelo menos algo no modo em que questionavam o tempo histórico usual.

Utopia revolucionária ("O futuro radioso") ou as versões dos fascismos que combinavam progresso com retorno a um passado mítico também desempenharam um papel na manutenção do moderno regime no poder. A despeito de tudo, a Segunda Guerra Mundial e seus desdobramentos não significaram o fim do regime moderno. Pelo contrário. Obviamente que não podendo abordar aqui este assunto, selecionarei um bem pequeno detalhe que, espero, diga algo. Em 1919, Lucien Febvre, iniciando 
como professor em Estrasburgo, na universidade recentemente reaberta, fez uma conferência inaugural sobre o tema: "A História num mundo em ruínas". Alí levantou a questão: Temos o direito moral de ensinar, de escrever história em época tão ruinosa? A resposta foi por fim, não por simples retórica, sim (Febvre 1920: 1-5). Em 1946, ele escreveu um editorial para os novos Annales, cujo título era "Defronte ao vento - Os Novos Annales". A diferença de atitude, pelo mesmo homem, em relação ao passado imediato é notável.

Assim, a despeito da catástrofe e por causa da impossibilidade de enfrentar o que viera de acontecer durante a guerra, e também por causa das várias estratégias de amnésia pessoal ou coletiva, o regime moderno de historicidade começou de novo a atuar muito bem. Palavras-chave tais como reconstrução, modernização, planificação, competição, confronto entre Leste e Oeste, mudanças econômicas e técnicas ou mesmo revoluções tiveram também uma parte importante na situação da Revolução e do novo mundo socialista. Em suma, o Progresso se apresentava como uma aceleração da aceleração anterior. O "Futuro radioso" socialista, o "Milagre alemão" capitalista ou "Os Trinta Anos gloriosos" da França foram os destaques! De uma tal conjunção pode-se, entretanto, constatar que o futuro ocupava cada vez menos lugar comprarado ao presente, que cada vez mais ganhava o primeiro plano: o presente e nada além do presente.

Mesmo que seu fortalecimento recente seja indubitável, tal foco posto no presente (por si e em si), que denomino presentismo, não constitui um fenômeno novo. O que temos experienciado no Ocidente ao longo do século XX é uma ênfase crescente no presente enquanto tal. O poeta T.S. Eliot, por exemplo, expressou a seu próprio modo este expansionismo do presente. "Em nossa época ... ganha existência uma nova espécie de provincialismo que talvez mereça novo nome. Trata-se de um provincialismo, não espacial, mas temporal; um para o qual ... o mundo constitui a propriedade exclusiva dos vivos, uma propriedade da qual os mortos não mais compartilham” (Eliot 1957:69). Os mortos não encontram mais seu lugar, nem mesmo qualquer lugar.

A valorização do presente contra o passado transpassa os inícios do século $\mathrm{XX}$ : a vida e o presente contra o passado associado à morte. Trata-se, por toda a Europa, 
de um tema literário, filosófico e político (White 1978: 27-50). Dentre outros, podese pensar em Nietzsche, Gide (L'Immoraliste), Ibsen (Hedda Gabler), Valéry ou mesmo Marinetti (seu Futurismo é bem um Presentismo). A historiografia profissional foi então confrontada com o novo desafio de estabelecer que um interesse pelo passado e um interesse pelo presente não se contradiziam um ao outro, sem reativar o antigo padrão da historia magistra. Se o passado enquanto tal não comportava uma lição direta para o presente, o problema seria transformá-lo, ou uma sua parte, em um passado relevante. Os primeiros Annales de Bloch e Febvre, com sua ênfase posta no presente (certamente que relacionado com as ambições da nova ciência social), compõem também uma resposta, de tipo histórica, àquele clima intelectual.

Um bom marco de um tal foco posto no presente, mas já com um deslocamento de tonalidade, é proporcionado por La Nausée de Sartre (1938): a "néantisation" do passado. Roquentin, o herói, é uma espécie de historiador, fazendo sua pesquisa sobre o marquês de Rollebon, um rapaz do século XVIII (um Talleyrand). Mas certo dia, ele descobre que não pode mais escrever seu livro: "A verdadeira natureza do presente se desvelava: é o que existe e tudo que não está presente não existe. O passado não existe. De modo algum" (Sartre s/d: 114). Este foi o livro fundante do que, após a guerra, se tornou o "Existencialismo". Assim, esqueça-se o passado, ou antes não há passado, nada além ou por trás do presente.

Esqueça-se o progresso, ou se o desafie à maneira rousseauniana. Aqui, podemos bem pensar nos Tristes Tropiques de Cl. Levi Strauss (1955). No contexto da descolonização, este livro, um advogado apaixonado em prol de Rousseau, com também recordações bem conscientes de Chateaubriand, reintroduz uma nova versão do tema do bom selvagem e constitui uma triste meditação sobre nossas sociedades modernas, baseadas em uma bem estreita idéia de progresso. O mundo iniciou sem o homem e terminará sem o homem: o primeiro equívoco foi a revolução neolítica! Assim antes do que antropologia, dir-se-ia "entropologia", ou ciência do fim do mundo! Nos anos seguintes, o selvagem tornou-se moda: ele tinha Pensamento próprio ("A Mente selvagem" ou o "pensamento mítico"), sua própria experiência política singular ou utópica (“o Selvagem contra o Estado”). 
O slogan "Esqueça-se o passado" constitui a contribuição dos anos sessenta para este retiro no presente. Houve então uma estranha combinação entre utopia ou aspirações revolucionárias (assim de orientação para o futuro) com um horizonte estritamente limitado ao presente. "Tout, tout de suite" (Tudo, tudo agora) diziam os muros de Paris em maio de 1968. E logo depois, apareceu a formulação: "Sem Futuro". Vieram desilusões, o fim das esperanças revolucionárias, a crise econômica de 1974, e com elas várias respostas, mais ou menos desesperadas ou por vezes cínicas: o presente, e nada além (diferente do humanista carpe diem, ou da valorização do presente por Montaigne).

Como a presença do presente, que crescia inexorável, inundasse tudo, um papel determinante foi certamente desempenhado pelas solicitações do mercado, o funcionamento de uma sociedade de consumo, as mudanças científicas e técnicas, os ritmos das mídias, que cada vez mais rapidamente tornam tudo (bens, acontecimentos, pessoas) obsoleto.

Assim fomos do futurismo para o presentismo e ficamos habitando um presente hipertrofiado que tem a pretensão de ser seu próprio horizonte: sem passado sem futuro, ou a gerar seu próprio passado e seu próprio futuro. Múltiplos sinais disto: nossas atitudes para com a morte, assim justamente estudadas por Ph. Ariès, a extrema valorização da Juventude, todas as técnicas que tendem a suprimir o tempo (o tempo do computador e o "tempo real").

Paro aqui esta breve e simples evocação (Nowotny 1989). Antes de passar às falhas do presentismo, como foi que a profissão histórica, eu perguntaria, respondeu a uma tal transformação? Nem diretamente nem imediatamente. Até os meados dos anos setenta, pelo menos na França, pode-se constatar que a longa duração e uma história econômica e social que faz contas e medidas ocupam o primeiro plano: até a "histoire immobile" de E. Leroy Ladurie é, de qualquer modo, bem distante da "écume des jours". Seguindo pelo mesmo caminho, mas em outro nível (as mentalidades), uma história que tende a etnologizar o passado tornou-se ativa sob o nome de antropologia histórica, de que J. Le Goff foi o mais proeminente praticante. 
Pode-se descobrir uma resposta bem mais direta à transformação no rápido desenvolvimento da história contemporânea, em torno da École Libre des Sciences Politiques e R. Remond, que bem rapidamente e cada vez mais se denominaram "a história do presente". Não apenas uma história do presente é possível, mas o presente, enquanto o ponto de que parte o historiador e para o qual ele volta, torna-se a categoria principal da reflexão histórica (Nora 1974: 225-226). História do presente e seus praticantes tendem agora a se apresentarem como o componente líder - tanto numérica quanto intelectualmente - da profissão.

As falhas do presente. Ao mesmo tempo este presente hipertrofiado rapidamente se tornou desconfortável em si mesmo. Ficou muito ansioso por ver-se como já passado, como história. Considere-se, por exemplo, o modo pelo qual a midia tem que produzir quase diariamente eventos "históricos". Mas, em termos mais amplos, o presente, mesmo no processo de realizar-se, gostaria de ver-se já ou de uma vez como, por assim dizer, com o olho da história: como um presente, que ainda não aconteceu completamente e já passou. Como um presente que seria para si mesmo seu próprio passado. Por outro lado, e de modo simétrico, está também extremamente preocupado com previsões e predições, isto é, projetar-se no futuro, notadamente por meios de um uso extensivo de pesquisas. Em quem você vai votar nas próximas eleições? o que você acha hoje imaginando o que você achará daqui a seis meses, e o que forem os resultados daqui a seis meses, eles são já os resultados. A pesquisa é uma ferramenta de previsão do futuro sem, por assim dizer, deslocar-se do presente. É uma fotografia, que de certo modo suprime o tempo. Mas, como sabemos, acontece que as pesquisas se equivocam!

Historia magistra apresentava a história, ou supostamente assim o fazia, do ponto de vista do passado. Pelo contrário, no regime moderno, a história foi escrita, teleologicamente, do ponto de vista do futuro. O Presentismo implica que o ponto de vista é explicita e unicamente o do presente.

Outra fenda apareceu no presente por meados dos anos setenta, tão bombástica mas já bem obcecada com predições: mostrou-se ansiosa acerca da questão da identidade, numa busca pelas raízes, uma ânsia de memória, preocupada com o "patri- 
mônio", atormentada pela conservação de monumentos, de lugares antigos ou não tanto, a preservação da natureza. Ansiosa com a recuperação do que fora perdido, ou estava para ser perdido ou inquieta com o que fora "esquecido" (especialmente a memória da II Guerra Mundial). Pode-se constatar a verdadeira "explosão" dos monumentos do Holocausto nos anos recentes em vários países ou, na França, o impacto do filme "Le Chagrin et la Pitié" (1971) de M. Ophuls. Rememoração, conservação ampla, ou renovação e reabilitação nas políticas urbanas têm valido contra a simples modernização, desafiando a sua até então inquestionada evidência.

Dois exemplos recentes ilustram esta mudança na atitude para com o tempo: o primeiro é Paul Touvier, este membro colaboracionista francês da milícia de Vichy. Ele realmente fez o que fez, mas o fato é que, em 1972, ele obteve do presidente Pompidou um perdão e, em abril de 1994, foi condenado. Em 1970, o mesmo Pompidou planejou a construção de um novo museu de arte contemporânea, Beaubourg, e a renovação de todo o distrito. Isto significou, antes de tudo, a destruição dos Halles, o antigo estômago de Paris. Em 1993, Miterrand inaugurou o Grande Louvre, com sua pirâmide transparente, que traz um toque (mas significativo) de pós-modernismo. O Louvre, que perdeu sua última função de regalia com a remoção das "Finances", é agora inteiramente um espaço de museu: o maior museu para a exibição do "patrimônio universal" da França.

Como consequiência visível dessa mudança, nosso atual presente tornou-se bem ansioso por comemorações, dando à vida política e cultural um "novo" ritmo. O bicentenário da Revolução foi a mais famosa, mas tivemos um número incrível de outras mais, a começar pelo milênio dos Capetos, que no início era uma brincadeira polêmica contra a celebração de 1789 e que terminou por uma missa solene assistida pelo Presidente da República! Três palavras tornaram-se o lema daqueles anos: memória (mas uma reconstruída, uma voluntária), patrimônio (o ano de 1980 foi decretado o "Ano do patrimônio"), comemoração (que não é de modo algum uma especialidade francesa, o que a Alemanha, por exemplo, faz muito bem) (François 1994: 62-70). Eles mesmos levaram à uma outra: identidade. Provavelmente a palavra-chave dos anos oitenta. 
Podemos constatar a reintrodução do futuro como uma perspectiva, primeiro (ou talvez apenas?) pela recente preocupação com a conservação. Como se tivesse que seguir este caminho indireto para ter significado. Aparece como um futuro pessimista, contrastando com a celebração anterior do Progresso como tal. O objetivo reside apenas em evitar ou corrigir os maus efeitos da modernização, retardar, antes de mais nada, o desastre ecológico próximo. Tomar em consideração o futuro implica subscrever uma apólice de seguro pelo futuro: contra o futuro. Temos aqui claramente um conflito imediato com as solicitações do presente. O futuro é um luxo que nem todo mundo pode se permitir, e na prática ninguém quando ocorre uma crise econômica geral, exceto se a Conservação como tal se tornar um valor admitido.

De qualquer modo, este presente, que venho descrevendo como aparentemente onipresente aparece também no todo inseguro e comporta dificuldades em tomá-lo como sua própria avaliação. Como se fosse incapaz de preencher a lacuna, que ele mesmo abriu, entre a experiência e o horizonte de expectativa. O passado está a bater à porta, o futuro à janela e o presente descobre que não dispõe de piso para ficar de pé. Pode-se imaginar um quadro de Magritte com este tema. Mas o que descrevo foi ou é a situação Ocidental. Como se passou, por exemplo, no antigo Leste à mesma época? Qual foi o status e a percepção do presente?

Então chegou 1989, inesperadamente, marcando o fim efetivo da ideologia que sempre se apresentara como o fio de corte do modernismo ou futurismo, e, se minha hipótese for tomada em consideração, uma nítida quebra ou mesmo o fim do regime moderno de historicidade. Pelo menos pode-se concordar que temos experienciado nos últimos vinte e cinco anos uma mudança profunda e veloz em nossas relações com o tempo. 1989 é a ocasião de tomarmos ciência dessa mudança e começar a trabalhá-la e dar-lhe um sentido. Não pretendo sugerir que 1989 signifique apenas isso, mas definitivamente também isso. Irá a velha máquina do regime moderno partir de novo? Obviamente, eu não sei. Primeiro, porque um fim significa também um novo começo e segundo, porque, se o novo regime foi "manufaturado" na velha Europa, o novo novo, o sobreveniente (se há um), está sendo ou será produzido em outro lugar. 
1989 também confirmou que a história de fato existe e que o historiador tem alguma responsabilidade, se não diretamente sobre ela, pelo menos a seu respeito (fazendo assim das especulações dos pós-modernismo histórico algo obsoleto). O futuro é imprevisível, não há nada de novo nisso. Mas o que seria um passado "imprevisível"? Para o historiador clássico o passado é o passado é o passado. Em meados dos anos setenta experienciamos um passado exótico: "o Mundo que perdemos". Esses foram os anos do grande e inesperado sucesso público do Montaillou de Leroy Ladurie e em termos mais amplos da assim dita Escola dos Annales.

Então veio um passado oculto, esquecido ou simplesmente falsificado (vinculado com o que acabei de dizer acerca do presente incômodo, que se tornou tão ansioso com a memória). Rememorar, não esquecer é apresentado como um dever pessoal dirigido a cada um de nós. Mas uma tal memória não é transmissão, mas reconstrução: história.

Um passado imprevisível significa algo mais: novas questões a colocar ao passado e, se possível, novas respostas de sua parte, considerando-o um campo de potencialidades, de que algumas começaram a acontecer, foram interrompidas, ou evitadas, ou destruídas (Ricoeur 1985: 313). Várias tentativas historiográficas recentes apontam nesta direção ou oferecem indicações mesmo que seu ponto de partida seja diferente. Penso, por exemplo, na micro-história, como praticada por G. Levi (1985). Mas se quisermos desenvolver seriamente um tal enfoque, muito provavelmente deveríamos aprender algo com os cientistas e os historiadores das ciências.

No que respeita a nossas relações com o tempo, esta reabertura do passado vai de par com o fato de tomar em consideração a dimensão do futuro. Não o futuro, com F maiúsculo. Mas mais modestamente devemos restaurar alguma forma de comunicação entre presente, passado e futuro, sem admitir a tirania de qualquer um deles. História escrita em nome do passado, do futuro ou do presente Precisamos estabelecer a ponte entre experiência e horizonte de expectativa, ou, para dizê-lo como o filósofo Paul Ricoeur, "tornar nossas expectativas mais determinadas e nossas experiências mais indeterminadas". 
A questão do ponto de vista constitui o último elemento. Em 1800, alguém observou: "Falta-nos totalmente um ponto de vista firme e estável" (1800). Assim estamos nós. Escrever uma história dominada pelo ponto de vista do futuro, como uma teleologia, não é mais possível, restaurar a antiga historia magistra poderia ser tentador, mas intelectualmente, e não intelectualmente, não muito satisfatório! E o presente mesmo, como acabamos de ver, não é um chão seguro. Assim o historiador não tem escolha, a não ser edificar um (seu) ponto de vista tão explicitamente quanto possível. A abordagem comparativa parece-me oferecer uma resposta possível: tanto modesta quanto complexa. Talvez, para dar um último exemplo, o interesse recente que ela desperta, especialmente na Alemanha, teria algo a ver com este problema de "orientação"? Quando os historiadores alemães enfrentaram a difícil e necessária tarefa de entender a história moderna da Alemanha, eles abandonaram o ponto de vista do Historismus (por razões óbvias), e elaboraram nas últimas décadas o que foi chamado de teoria Sonderweg (caso especial), que tomou, para citar J. Kocka, "desenvolvimentos ocidentais (ou ocasionalmente mais uma sua versão idealizada) por modelo e padrão, e avaliaram em que medida os desenvolvimentos alemães coincidiam com ou divergiam deles" (1993: 369-379). Isto é o que Kocka chama de "comparativismo fraco". Então, o debate provocado pela explanação Sonderweg levou a estudos comparativos cada vez mais explícitos e controlados. Ora, como se escreveria a história da RDA? Do ponto de vista da Alemanha ocidental, ou como uma catástrofe anunciada? Não, mas antes reescrevendo a história de toda a Alemanha, elaborando uma lista comparativa de questões. Se algum dia viermos a ter histórias Européias, elas não podem ser a mera justaposição de histórias nacionais, mesmo que financiadas por Bruxelas!

Mas o que é ou pode ser uma história nacional? Por algum tempo os historiadores acharam que estavam livres desse problema, a não ser que escrevessem manuais escolares e a despeito do fato de que muito de sua pesquisa fosse realizada naturalmente em um enquadramento nacional. Mas a nação parece de novo um fato inevitável e uma questão insistente, ou mesmo sangrenta. Como escreveríamos história nacional, sem reativar os padrões da historiografia do século XIX, ou seja, com a 
estreita associação de progresso e nação (a nação como progresso e a história como progresso da nação), ou sem apresentar a nação como um paraíso perdido? É aqui que seria especialmente útil ser capaz de reabrir o passado, e olhá-lo como um conjunto de passados que foram uma vez futuro possível e mostrar como a via do Estado nacional, com sua historiografia nacional ou nacionalista, geralmente foi a vencedora. Nesta perspectiva, valeria a pena estudar, como estudos de caso ou como sintomas, as respostas dadas, por exemplo, por Th. Nipperdey em sua História da Alemanha, por F. Braudel em sua A Identidade da França, ou ainda mais recentemente por P. Nora em seu Lugares da memória, que são ao mesmo tempo um diagnóstico do presente, um sintoma do presentismo e uma via para dele escapar.

\section{Referências Bibliográficas}

BENJAMIN, W. Gesammelte Schriften. I.2, Suhrkamp, Frankfurt/M, 1974, p. 704.

BOTTÉRO, J. "Symptoêmes, signes, écritures". In: Divination et Rationalité. Paris, Editions du Seuil, 1974, p.70-193.

BRAUDEL, P. “La Longue Durée”In: Écrits sur l'Histoire, Flammarion, Paris, 1969.

CHATEAUBRIAND. Mémoires d'Outre-Tombe. La Pléiade, Gallimard, Paris, 1951.

CONSTANT, B. “De la liberté des Anciens comparée à celle des Modernes” (1819).

ELIOT, T.S. On Poetry and Poets, London, 1957.

FEBVRE, L. "L'Histoire dans le monde en ruines". In: Révue de Synthèse Historique, Février 1920, p.1-15.

FRANÇOIS, E. 'Nation retrouvée, nation à 'contre-coeur'. L'Allemagne des commémorations”. In: Le Débat, 78, 1994, p. 62-70.

FUKUYAMA, F. “The End of History, Five Years Later". In: History and Theory, 34, 1995, p. 27-44.

GLASSNER, L.-J. Chroniques mésopotamiennes. Paris, Les Belles Lettres,1993.

GRAFTON, A. "Come gli Antichi divennero classici”. In: Storia d'Europa, dir. J. Guilaine S. Settis. Turim, Einaudi, 1994, 1401-1405.

HARTOG, F. "Premières Figures de l'Historien: historicité et histoire", 1996.

HARTOG, F. 'La Revolution Française et l’Antiquité”. In: La Pensée Politique 1, 1993. 
HARTOG, F. “Les Anciens, les Modernes, les Sauvages ou le Temps des Sauvages”, dans Chateaubriand: le Tremblement du Temps. Toulouse, Berchet, Presses Universitaires du Mirail, Toulouse, 1994, p. 177-200.

KEMP, A. The Estrangement of the Past. A Study of the Origins of Modern Historical Conciousness. Oxford U.P., 1991.

KOSELLECK, R. Futures Past. On the Semantics of Historical Time. Cambridge, MIT Press, 1985.

LEVI, G. L'Eredita immateriale, Einaudi, Turin, 1985. "Comparative Historical Research: German Examples". In: International Review of Social History, 38, 1993, p. 369-379.

NORA, P. "le retour de l'evenement". In: Faire de l'Histoire, Gallimard, Paris, 1974, vol 1, p. 225-226; ver Écrie l'Histoire du Temps Présent. En hommage à François Bédarida. CNRS Editions, Paris, 1993.

NOWOTNY, H. Eigenzeit: Entstehung und Sturkturierung eines Zeitgefühls. Suhrkamp, Frankfurt, 1989, cap. 2.

RICOEUR, P. Temps et récit III. Editions du Seuil, 1985, p. 313.

SARTRE, J.-P. La Nausée. Paris, Gallimard, p. 114.

STAROBINSKI, J. Montaigne en mouvement. Paris, Gallimard, 1982.

SZONDI, P. "Espoir dans le temps passé”. In: Sur Walter Benjamin, s/d., p. 43.

VALÉRY, P. Cahiers II. La Pléiade. Paris, Gallimard, 1974.

WHITE, H. "The Burden of History". In: Tropics of Discourse. Baltimore, The John Hopkins U.P., 1978, p. 27-50. 